\title{
ISLAMIC PERPECTIVE EXPLORATORY REVIEW: CREATIVE MULTIMEDIA TECHNOLOGY AS AN INNOVATIVE TOOL FOR DA'WAH DISSEMINATION
}

\begin{abstract}
Abstrak
Multimedia ditakrifkan sebagai gabungan beberapa media komunikasi seperti audio, video, teks, dan lainlain untuk menghasilkan kandungan artifak buatan kreatif. Pada masa kini, orang yang hidup di lebuh raya maklumat era teknologi komunikasi super koridor di mana mereka tidak dapat membayangkan diri mereka tanpa kemajuan teknologi ini. la boleh menjadi satu manfaat atau bencana bergantung kepada orangorang yang membuat keputusan atas arahan penggunaannya. la bergantung kepada bagaimana kita melihat ke dalam perspektif pelbagai teknologi. Teknologi komputer dan ICT bukan hanya pemboleh untuk meningkatkan desiminating pengetahuan tetapi ia juga menyediakan platform untuk membangunkan masyarakat berpengetahuan yang lebih baik di seluruh dunia dengan berkesan. Oleh itu, kertas kajian ini bertujuan untuk menjalankan kajian kritikal Multimedia Kreatif dari perspektif Islam dan elemen-elemen Multimedia seperti realiti maya, pangkalan data dan privasi isu. Beberapa evicences membentuk Kitab Suci (Al-Quran) juga digunakan sebagai rujukan untuk kajian ini kritikal. Kertas penyelidikan menyimpulkan sokongan terutamanya daripada Kitab Suci (Al-Quran) dan amalan Nabi Muhammad (saw). Di harap para penyelidik lain akan mendapat manfaat hasil daripada kajian sorotan ini.
\end{abstract}

Kata kunci: Perspectif Islam, kreatif, multimedia, realiti maya, pangkalan data, privasi

\footnotetext{
* Profesor di Kuliah Teknologi Komunikasi dan Maklumat, Universiti Islam Antarabangsa

** Pelajar Prasiswazah di Kuliah Teknologi Komunikasi dan Maklumat, Universiti Islam Antarabangsa

*** Pelajar Prasiswazah di Kuliah Teknologi Komunikasi dan Maklumat, Universiti Islam Antarabangsa

**** Pelajar Pascasiswazah di Fakulti Teknologi Kreatif dan Warisan, Universiti Malaysia Kelantan
} 


\begin{abstract}
Multimedia is defined as the combination of several communications media such as audio, video, text, etc to produce the creative content artificial artifact. Nowadays, people live in the super corridor highway information communication technology era where they cannot imagine themselves without this technology advancement. It can be a benefit or a disaster depending on people who decide on the direction of their use. It depends on how we look into multiple perpectives of the technology. The computer technology and ICTare not just enable to enhance the dissemination of knowledge but they also provide the platforms to develop better knowledge of society around the world effectively. Thus, this research paper is meant to conduct a critical review on Creative Multimedia from Islamic perspective and the elements in Multimedia such as virtual reality, database and privacy issues. Several evidences form the Holy Book (The Quran) which is also used as reference in this exploratory review. This research paper uses to support arguments presented Holy Book (The Quran) and the practices of Prophet Muhammad (peace be upon Him).
\end{abstract}

Keywords : Islamic Perspectives, creative, multimedia, virtual reality, database, privacy 


\subsection{Introduction}

Al-Quran contains beautiful verses and creative signs from Allah. Islam teaches people that the whole universe and everything in it is Allah's creation. Everything other than the Creator came out of the will and commandment of Allah the Creator. If He had not exercised His creative fiat, people would not have been here to know Him or to think of Him. In the Holy Quran Allah Almighty says what means:

\section{And I did not create the jinn and mankind except to worship Me. (Adh-Dhariyat :56)}

And worship in its essence means knowledge of the worshippers that they owe God what is due to Him, namely their sincere gratitude to Him for their very existence, as well as all the blessings they enjoy in this world. Another "signature" of Allah's creative power of its strongest stated in Al-Quran are:

..And He creates that which you do not know. (An-Nahl : 8)

..Allah creates what He wills. Indeed, Allah is over all things competent. (An-Nur : 45)

From both verses, it indicates that Allah has not 'finished' creation; rather, it is an ongoing process. Al-Quran can be considered as a creative creation from the The Almighty Allah. We can find so many verses that keep repeating to attract attention of people to read and understand especially for Muslims and also non-Muslims. The privilege of Al-Quran is the Quranic verses are interrelated to each other. This is to show evidence of Allah Almighty for those who believe. Al-Quran also shows many stories of the Prophets. For example story about Prophet Sulaiman and Princess Balqis. Surah Al-Naml verse 20 to 44 mention the story of Prophet Sulaiman who invites Princess Balqis (ruler) of a state to embrace Islam, which is only to worship Allah.

Another story is stated in Surah Al-Isra' verse 1; about the Prophet Muhammad PBUH made his night journey from Mecca to Jerusalem, and thence to heaven. His journey, known in history as Mi'raj (Ascension), was a real bodily one and not only a vision. It was at this time that Allah ordered the Muslims to pray the five daily prayers. The way Al Quran describes the stories of Sahabah in a creative way is actually helps Muslims (even non-Muslims) to understand Al Quran easily.

As we know, Information \& Communication Technology (ICT) can be used as a tool to deliver a message to all people around the world. There are many branches of knowledge that can be found under ICT. Among the most popular is Multimedia. Lawrence (1996) defined that;

Multimedia is the use of text, graphics, animation, pictures, video, and sound to present information. Since these media can now be integrated using a computer, there has been a virtual explosion of computer based Multimedia instructional applications. 
These applications run the gamut from serious computer-based tutorials for adults to the new category of "edutainment" products for children. These very diverse applications seem to share acommon assumption-Multimedia information helps people learn (Definition Section).

As stated in a hadith,

"Every one of you is a caretaker, and every caretaker is responsible for what he is caretaker of" (Narrated by Imam Bukhari).

So, as a "caretakers", the Muslims need to equip themselves with ICT skills especially Multimedia to enhance students' learning by making the learning process not only exciting and enjoyable, but effective as well. Multimedia allows teachers to use a combination of technology tools to appeal to an array of learning styles digitally. If integrated properly, Multimedia also have the capability to stimulate imagination and develop critical thinking skills while allowing students to take an active role in their own learning.

Many Muslims do not realize how big the area of Multimedia. Through Multimedia, Islamic teaching can be introduced and implemented. Therefore this research aims to investigate the role that can be played by Multimedia in enhancing people's knowledge about Islam. As what The Prophet Muhammad (peace be upon him) said,

"The seeking of knowledge is obligatory for every Muslim" (Al-Tirmidhi, Hadith 74)

Hence, as a Muslim, it is compulsory to learn and master the skills of Multimedia in order to spread the teachings of Islam.

\subsection{Literature Review}

Multimedia provides a medium for Muslims to promote the understanding of Islam. Multimedia in Islam allows people to know more about Islam, specific to Shariah compliance: What is good and what is wrong. For a Muslim who believes in Allah's power, human achievement in ICT is a sign of knowledge achievement that in fact need to be used in order to find the truth. As Allah said in the Qur'an,

"We shall show them our signs on the horizon, and their own souls, until it becomes clear to them that it, namely, the Qur'an, is the truth, it is not sufficient that your Lord is the witness to all things" (Fussilat: 53). 
Through this Quranic verse it is clearly shown that Muslim generation can use Multimedia to seek the truth about Islam. Nowadays people especially a young generation is likely more interested to learn about Islam through what they see and what they heard. By using Multimedia, they can understand the basic thing and sometimes the misunderstanding about Islam can be eliminated. Allah stated in the Qur'an,

"Invite to the Way of your Lord (i.e. Islam) with wisdom and fair preaching, and argue with them in a way that is better. Truly, your Lord knows best who has gone astray from His Path, and $\mathrm{He}$ is the Best Aware of those who are guided (An-Nahl: 125).

Muslims should realize that Da'wah is an obligation upon them. The Prophet (p.b.u.h.) has said,

"Convey from me, even one verse." (Bukhari).

This shows the importance of Da'wah. What is the relation between Da'wah and Multimedia? By using Multimedia, it can help Muslim to tell the world exactly how Islams is. It can be said that in Multimedia sector, there must be a Muslim since nowadays we can see so many things that against Islamic rules. We need to bring back the glory of Islam. With that, we need Muslims to know the skills in Multimedia.

Multimedia has a strong correlation with another field of ICT which are virtual reality, Database and Privacy. The usage of these fields is actually explaining the way Multimedia works.

\subsection{Islamic Perspective Review on Virtual reality}

Virtual reality is one of the signs of Allah on the Day of Judgement. Allah will tell us all what we have practiced, whether we remember or forget. All of the deeds were stored in the record and will be presented and displayed to us by Allah on that day. All thoughts, actions, including things that we already forgot. Indeed, the Qur'an tells us that all things are possible, including the smallest deeds. Allah mentioned about virtual reality in Surah Al-Qamar and Ali-'Imran:

"And everything they did is in written records. And every small and great (thing) is inscribed." (Al-Qamar: 52-53) 
Man always forgets, but Allah never forgets. Therefore, the fault people cannot distance himself from guilty.

Say, "Whether you conceal what is in your breasts or reveal it, Allah knows it. And He knows that which is in the heavens and that which is on the earth. And Allah is over all things competent. The Day every soul will find what it has done of good present [before it] and what it has done of evil, it will wish that between itself and that (evil) was a great distance. And Allah warns you of Himself, and Allah is Kind to (His) servants." (Ali-'Imran: 29-30)

On that day, Allah will resurrect all of them and He will tell them about their deeds.

\subsection{Islamic Perspectives Review on Database Concept and Implementation}

Allah stated in Az-Zumar verse 10:

"There should always be among you some people who invite what is good and enjoin what is right and forbid what is wrong: They alone will attain true success. And do not be like those, who became divided into sects and got involved in differences of opinion even after receiving clear teachings".

Whoever is doing any work (Multimedia in specific), must be the one who follows Allah's order according to this above verse. It is fardu 'ain (obligatory) to all Muslims to take this responsibility in order to prevent munkar that is widely happening without being stopped. It is also stated in Surah Fussilat verse 33

"And who is better in speech than he who [says: "My Lord is Allah (believes in His Oneness)," and then stands straight (acts upon His Order), and] invites (men) to Allah's (Islamic Monotheism), and does righteous deeds, and says:"l am one of the Muslims." 
"O you who believe! Avoid most of suspicion, for surely suspicion in some cases is a sin, and do not spy nor let some of you backbite others. Does one of you like to eat the flesh of his dead brother? But you abhor it; and be careful of (your duty to) Allah, surely Allah is Oft-returning (to mercy), Merciful" (Hujurat: 12)

Suspicion: The focal point of the above verse is to shed light on the hidden and secretive sins that are prevalent amongst the Muslims. The fact that these sins are born, sustained and conducted from within one's self gives it a more lethal effect in destroying Islamic brotherhood. Islam seeks to uproot and destroy these evils from the very beginning.

Suspicion is the stepping-stone that the Shaytaan uses to exploit the Muslims to the other evils mentioned in the verse, namely; backbiting, gossip and spying. Suspicion leads to distrust and lack of trust among the people. It breaks down the strength of brotherhood. Once suspicion is eliminated from the minds of people, trust will grow. Otherwise people will be at each other's throat for every slip of the tongue and misunderstood statement. Nowadays, technology do involve in growing this suspicion among people. There is a lot of Multimedia video even television programs allow spying on people's privacy in orders to get the highest rating.

It is reported that Umar Ibn Khattab (Radhi Allahu anhu) entered upon a person drinking wine. He said: "Have I not forbidden you to drink wine and you did that?" They said: "O Amir (leader) of the believers, Allah has forbidden you to spy and you spied on us, and Allah forbade you to enter the houses without asking permission, and you did enter without permission." Umar (Radhi Allahu anhu) said: "These (your sins) in return for my mistakes." Then he left and didn't interfere or prevent them. Also, when al-Waleed Ibn Uqbah was brought to Ibn Mas'ood (Radhi Allahu anhu) and charged with having been found with wine dripping from his beard. Ibn Mas'ood said: "We have been forbidden from spying but, if any evidence appears in the open we will use it." [Sunan Abu Dawood, Eng. Trance, Vol: 3, no: 4875]

Thus, even if Haraam is done secretly we are not asked to spy. 


\subsection{Methodology}

Grounded Theory and Content Analysis approach had been used as a systematic approach conduct in this exploratory review of the Holy Book (The Quran) in looking for the evidences - as the main sources and several academic articles. Figure 1 illustrates the overview of the methodology used for this study

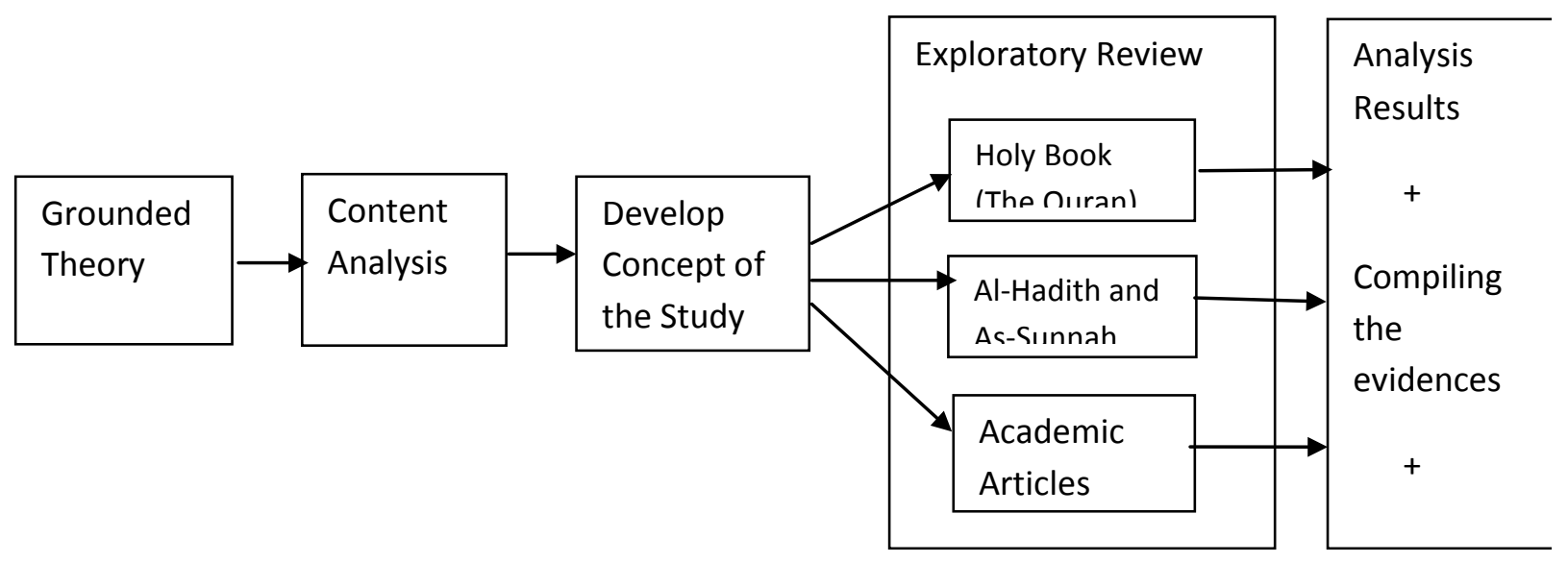

Figure 1: Methodology Overview

\subsection{Results and Discussions}

As what has been mentioned in Surah Fussilat verse 53, Muslims should use ICT (Multimedia) in order to find the truth about Islam. Sometimes a Muslim, does not have deep knowledge with regard to Islam. They are searching so many ways to find it. It is a waste if Multimedia is not being used to provide the truth/ knowledge, for example, by using television. Television is a part of Multimedia. A child or an adult often spends their leisure time watching television. So, they can gain something that benefits them as a Muslim if they know how to choose television shows. According to Zin et al. (2012), for the children, exposure to Multimedia tools embedded unnoticed. With selective selection, viewing television programs can facilitate learning. Zin et al. (2012, as cited in Rezki Perdani Sawai et al, 2009), television is one of the Multimedia and watching is not a passive behavior. Children will actively view the material processing. They will respond to auditory and visual display as well as considering whether to watch or not. In addition to the entertainment, children and adults often use television as a learning tool, especially when it involves consideration of "cause and effect". Therefore, Multimedia is the best way to seek basic knowledge. 
Furthemore, multimedia can also help the Muslims to spread Da'wah. Rosydi Muhammad and Marjan Muhammad (n.d) stated that, "since ICT is the global-focused technology, it is believed that it can be the most useful platform for Muslims to disseminate Islamic knowledge and information". According to Juhana, Sharhida and Shahizan (n.d) in Islamic Da'wah nowadays, it is important for preachers to equip themselves with knowledge contained in the Qur'an and Sunnah and control technology in spreading the Da'wah. Muslims should consider how modern equipment can be used for acquiring knowledge, the dissemination of ideas and thoughts in a more simple, powerful and effective.

\subsection{Virtual Reality Application for Islamic Da'wah Dissemination}

Multimedia can also be embeded to virtual reality environment. It is because it uses an element such as virtual reality. Virtual reality is a computer-simulated environment that can simulate the physical presence in places in the real world or imagined worlds. Most current virtual reality environments are primarily visual experiences, displayed either on a computer screen or through special stereoscopic displays, but some simulations include additional sensory information, such as sound through speakers or headphones. This technology development involves 3D simulation that is widely used in engineering, design and medicine fields. It gives opportunity to users to feel something live and real situation wherever they are using this kind of technology (Muhd Rosydi Muhammad and Marjan Muhammad, n.d).

Virtual reality nowadays is widely used in the educational field. This gives advantages to teachers in teaching and disseminating knowledge to students. Students will enjoy learning new things whenever they are exposed to such a thing. Another advantage is that it enables a large group of students to interact to each other as well as with a three dimensional environment. Virtual reality technology has been widely proposed as a major technological advance that can offer significant support for education. There are several ways in which Virtual Reality technology is expected to facilitate learning. This ability can construct knowledge in a learning-by-doing situation (Youngblut, C.,1998). According to Soo-Phing, B. et al (2007) these kinds of things prove to be a feasible and viable alternative to traditional classrooms. It is able to present complex data in an accessible way to students which is both fun and easy to learn. Plus these students can interact with the objects in that environment in order to discover more about them. Hence, virtual reality environment must follow Islamic principles as guidance. If people implement Islamic principles in this world, they should also implement it in virtual reality (Mohamad Fauzan Noordin, 2009). 


\subsection{Database Concept and Technology for Malaysian Islamic Digital Content}

According to Abderrahmane Azzi (1998), Multimedia is a term for "any content that combines text, sound, graphics, and video". This definition can be viewed, from a mass communication perspective, as a description of a medium which targets many of our senses (vision, hearing, etc.). The development of Multimedia seems to have restored, what McLuhan termed a long time ago, as the balance in our "sense-ratio." The issue, however, is not so much related to our sense perceptions as it is in this new wave of interactive communication which has transformed the way people communicate, behave and conduct their businesses. It is not just that Multimedia accelerates the process of transmitting data documents and images; the new media provides unprecedented access and create a social cyberspace environment characterized by new communication phenomena such as news group communication, virtual communities etc. The content that exposed or viewed in any sort of Multimedia automatically do affect the social environment and people who live in it.

Stated by Abderrahmane Azzi (1998) Malaysia is probably the first Muslim country to develop an ambitious program to use Multimedia technology in business, education and development. The program, called the Multimedia Super Corridor (MSC), will support all sorts of Multimedia and information technology with video conferencing functions and complete automation. So, those are learning and get the opportunity to conduct the Multimedia program should take responsibility in order to create the cyberspace and reality to live in a better place and bring what Allah has demanded Muslim.

\subsection{Creative Multimedia Privacy Issues}

The person involves in Multimedia should give end users or readers' benefits and good information instead of gossiping or spreading others' privacy. For example, a lot of video about spying or television program such as Melody have made people go against Islamic order. According to the A. S. QASEM (2004), Gaining unauthorized access to people's private information is prohibited whether such information is a message sent over a network, the email messages of a user in his/her Inbox, etc. Seriously, nowadays viewers can not really differentiate either some sort of Multimedia is a privacy or needed to be entertained. 
According to Mohamad Fauzan Noordin (2013) privacy in cyber world is most essential as one can enjoy, explore, disclose, use and disseminate other personal information for bad intention. In this situation, the intention might be for embarrassing, faking the genuine information and others. Moreover, Mohamad Fauzan Noordin (2013) also stated Internet and Computer Users: The growth of computing technology especially the Internet era has made possible the accumulation and information from vast amounts of data on each individual. This situation has affected both the general public's view of privacy and the issues of protection of personal information. All kinds of Multimedia should expose the true matters because Multimedia has become a main method in educating people. People rely on Multimedia to get news, educations and many more. Even for entertainment, the Multimedia show to people must educate people, not influence people to spying, gossiping or any act against good behaviors.

This paper attempts to review hospital building maintenance by using a quality function deployment concept. Some issues that can be highlightedarepoor maintenance program in place for hospital buildingsin Indonesia, which are necessary to provide public health and medical treatment to citizens. Thus, an improve maintanence strategy is required in order to provide the necessary services and gain customer satisfaction. In addition, to determine an optimal maintenance strategy for a building, it is necessary to integrate the three types of maintenance strategiesasnot all items are significant;not all significant items can be condition monitored;condition monitoring techniques are not always available; andthe application of condition monitoring techniques is not always cost effective. Furthermore, QDF is one of methods that is appropriate to use to improve hospital building maintenance in order to fulfill customer and stakeholder expectations. 


\subsection{Conclusion}

Multimedia is a part of achievement in ICT that gives more understanding to people and they gain knowledge from it. These chances should be used in order to get pleasure from Allah in this world. People that use this existence of technology should help them to get closer to Allah. Hence, Muslims need to equip themselves with information and knowledge of this advent technology which acts as the most powerful strength and power. It will enable Muslims to compete and survive in this competition.

Therefore, to integrate Multimedia with Al-Quran, these two should be widely developed as a free software and an alternative method of society to learn Al-Quran. This application usually uses a Flash movie which was more complex and more interactive, XML database to store the surah of Al-Quran and programming language to write the code.

Allah clearly encourages Muslims to furnish themselves with power and strength as He says in the Holy Quran in Surah Al-Anfal verse 60:

"And be prepared (equipped) yourself with all of your efforts in gaining strength ..." 


\section{References}

Al-Quran, Surah Adh-Dhariyat: 56.

Al-Quran, Surah An-Nahl: 8 and 125.

Al-Quran, Surah An-Nur: 45.

Al-Quran, Surah Fussilat: 53 and 33.

Al-Quran, Surah Al-Qamar: 52-53.

Al-Quran, Surah Ali-Imram: 29-30.

Al-Quran, Surah Az-Zumar: 10.

Al-Quran, Surah Al-Hujurat: 12.

Hadith narrated by Imam Bukhari.

Hadith Al-Tarmidhi, Hadith 74.

Hadith Bukhari.

Sunan Abu Dawood Vol: 3, no: 4875.

M. Z. Mohd Zin, Mohd Syahiran Abdul Latif, Azri Bhari, Rohaya Sulaiman, Azhar Abdul Rahman, Ahmad Faisal Mahdi \& Mohd Sapawi Jamain, 2012. Asian Social Science: Education Quality Enhancement via Multimedia Technology, Centre For Islamic Thought and Understanding, University Technology Mara (Vol. 8, No. 10).

Lawrence J. Najjar, 1996. Multimedia Information and Learning: Jl. Of Educational Multimedia and Hypermedia 5 (2), 129-150, School of Psychology Georgia Institute of Technology, Atlanta.

Juhana Salim, Sharhida Zawani Saad, Mohd. Shahizan Othman, 2011. Using Bioinformatic Strategically for Islamic Da'wah: Jurnal Hadhari 3 (1) 1-20.

Muhd Rosydi bin Muhammad, Marjan binti Muhammad. (n.d). Using Information and Communication Technology (ICT) to Disseminate the Understanding of Islamic Jurisprudence (Fiqh) and Juridicial Opinion 
(Fatwa): A View of a Technologist. pp.1-27.

Christine Youngblut, 1998. Educational Uses of Virtual Reality Technology. Institute for Defense Analyses.

Dongsong Zhang, 2005. Interactive Multimedia-Based E-Learning: A study of Effectiveness. Pp. 151. The American Journal of Distance Education, 19 (3), 149-162.

Mohamad Fauzan Noordin, 2013. Application of Privacy, Security and Ethics in Islamic .Concerned ICT Middle-East Journal of Scientific Research 14 (11): 1548-1554.

Abderrahmane Azzi, 1998. Multimedia and Communication Curricula: The Medium vs. the Message .Intellectual Discourse Vol 6, No 2, 123-136.

A. S. Qasem,2004. Privacy: ICT and Islam.

Mohamad Fauzan Noordin,2009. ICT and Islam. IIUM Press, IIUM. p.101. 